\title{
Food commodity market under uncertainty: regulation of access and influence on decision making
}

\author{
Tatiana Skryl ${ }^{1, *}$, and Marina Gregoric ${ }^{2}$ \\ ${ }^{1}$ Plekhanov Russian University of Economics, Stremyanny per., 36, 117997 Moscow, Russia \\ ${ }^{2}$ University North, Trg dr. Žarka Dolinara 1, 48000 Koprivnica, Croatia
}

\begin{abstract}
The article reveals the principles of functioning of food products market in Russia in conditions of uncertainty. The current reality has arisen not only because of the decisions of foreign countries in the field of international trade, but also because of the emergence of threats to the lives of the population through the spread of a particularly dangerous infection throughout the world. Governments of many countries had to accept the new conditions of uncertainty as an objective necessity to reconstruct the economic system, identify weaknesses in the economy and build mediumterm plans for the development of trade relations between the countries. The author cites the market of agro-industrial complex as the object of analysis of this research. In the course of the work, the place of Russia in the structure of export and import of food products was considered, the foreign trade balance for the last three years was calculated, and the barriers to entry into the market of food products in the near future were assessed. In conclusion, it is highlighted that the state, by building a sustainable institutional environment under conditions of limited rationality, influences the decisions of the country's food market participants in order to ensure the competitiveness of the sector of the economy.
\end{abstract}

\section{Introduction}

The role of the food market in the stable operation of any country's economic system remains a priority, especially at a time when not only military risks can hinder the functioning of the economy. Conditions of uncertainty arise not only because of the decisions of foreign countries in the field of international trade, but also because of the emergence of threats to the lives of people through the spread of particularly dangerous infections around the world. Watching the process of destabilization of the economy under the influence of epidemiological situation, we can safely say that, providing the work of one sector of the economy, one has to sacrifice the functionality of another. Here we mean the situation that emerged in the spring of 2020 as a result of restrictive measures to spread the Covid-19 virus. In order to ensure a stable and effective health sector, while avoiding overburdening hospitals and medical staff, many governments have restricted access to catering, entertainment,

\footnotetext{
*Corresponding author: t_skryl@mail.ru
} 
cultural and mass sports facilities. This led to a qualitative distortion and redistribution of income and expenditure flows in each country's economic system. Based on the Fisher Clark three-sector model, the economy, having gone through all three stages of development from agrarian, industrial to information, has returned, reducing temporarily the share of employment in the service sector. The link in the three-sector model is the food market, as it combines both the extractive sector of the economy (agriculture) and the industrial sector (production of goods and services (transportation, services) [8].

At present, there is a problem of efficient operation of the food products market without the participation of a third party represented by state structures. It is assumed that due to the unequal distribution of information about the object of sale, the intentional narrowing of access to the market and the influence of external externalities, the participants of the food products market are in a zone of limited rationality and cannot take economically beneficial decisions.

Shortly before the introduction of sanitary-epidemiological measures in Russia, the "Doctrine of Food Security of the Russian Federation" was approved, which specifies the directions, goals and objectives of the state socio-economic policy in the field of food market functioning. According to the adopted Doctrine, food security is defined as follows: "Food security of the Russian Federation is a state of social and economic development of the country, which ensures food independence of the Russian Federation, guarantees physical and economic accessibility for every citizen of the country of food products that meet mandatory requirements, in the amount not less than rational norms of consumption of food products necessary for active and healthy way of life".

The purpose of the study is to identify the relationship between the regulation of export by the state of the main food suppliers and the decision-making procedure of domestic producers of food products.

Scientific novelty of the study reflects that the essence of the food market is expressed in the stable supply of the country with the main types of domestic agricultural products, raw materials and foodstuffs and maintenance of solvent demand. One of the main reasons for problems with making economically correct decisions on the food market should be considered the refusal of the state to support domestic agricultural producers and unjustified import of food to the market [12], as well as weak institutional environment, which includes customs rules and regulations. It becomes obvious that the role and importance of the state in addressing the issues of efficient operation of the food market and its competitiveness is quite large and should only be strengthened in the future [4].

\section{Materials and methods}

Justification of decisions made by economically rational agents, coordination of their actions, choice of the direction of economic growth - these are not all the questions to which classical economic theory should answer. Efficient resource allocation and market development are justified by a new institutional approach that combines the origins of the Austrian institutional school and classical economic theory $[3,5,13]$. Uncertainty of the environment creates difficulties for further strategy selection [10]. The main methods used in this study are statistical methods of studying the economic situation and business activity, institutional and comparative analysis, including those based on behavioral economics.

For the first stage of the selection, we will take the agro-industrial market for analysis and determine Russia's place in the structure of food exports and imports.

The undisputed leader of agro-industrial complex export by the end of 2019 is the USA, the export volume amounted to $\$ 142$ billion, which exceeds Russian agro-industrial complex export by 5.5 times. The United States is one of the world's largest players in the food market. The main products for export to the U.S. are soybeans, corn, nuts, wheat, pork. 
The Netherlands is the largest in the European Union and the second largest exporter of agricultural products and food in the world. In particular, the country is a leader in dairy production and is also a major player in the world market as a seller of cheese, onions and fresh vegetables. In 2019, the Netherlands exported products worth 109 billion dollars, which is almost a quarter less than the U.S. export volume. The country in its turn surpassed such world competitors as Germany (by 1.3 times), Brazil (by 1.4 times), China (by 1.4 times), France (by 1.5 times) by export indicator. By the end of 2019 the export of Russia was 4 times exceeded.

It is obvious that the current volume of Russian exports lags behind the Belgian one, which completes the top 10 agricultural exporting countries, almost 2 times.

This situation creates an objective need to constantly increase the efficiency of Russian producers so that they could successfully compete with companies from the largest food exporting countries [1].

On the other hand, the largest exporting countries are also the largest food importers. Many experts believe that Russia should not seek to completely replace the supply of foreign agricultural products with domestically produced goods.

Thus, the situation on the world agricultural export market creates the need to constantly increase the efficiency of Russian producers so that they could successfully compete with companies from the largest food exporting countries. However, Russia should approach this issue with caution and monitor the overall trade balance of the country.

Geographically, Russian food exports are increasingly shifting towards Asia, the Middle East and Africa. No less interesting is the country structure of food export (Table 1).

Table 1. Top 10 purchasers of Russian food in 2019 [6]

\begin{tabular}{|c|c|c|}
\hline Positions in 2019 & Country & $\begin{array}{c}\text { Volume of } \\
\text { agricultural products } \\
\text { imported from Russia } \\
\text { (million USD) }\end{array}$ \\
\hline 1 & China & 3202 \\
\hline 2 & Turkey & 2491 \\
\hline 3 & Kazakhstan & 1809 \\
\hline 4 & South Korea & 1560 \\
\hline 5 & Egypt & 1470 \\
\hline 6 & Belarus & 1352 \\
\hline 7 & Netherlands & 1033 \\
\hline 8 & Iran & 974 \\
\hline 9 & Ukraine & 711 \\
\hline 10 & Azerbaijan & 623 \\
\hline
\end{tabular}

The largest buyer of Russian agro-industrial complex products in 2019, as in the previous year, was China. China is Russia's strategic partner, with a geographically convenient location and a huge consumer market. In 2019, this country imported more than USD 3 billion worth of agri-food products from Russia. China accounts for $15 \%$ of Russia's total food exports. The main positions of Chinese agro-import from Russia are frozen pollock, sunflower oil and crabs.

The second place among importers of Russian agricultural products is occupied by Turkey - a major buyer of Russian grain, corn and sunflower oil. The total volume of Russian food products amounted to almost $12 \%$ of all food exports ( $\$ 2.5$ billion).

The third line is Kazakhstan. Bakery and flour confectionery, chocolate, as well as cigarettes are leading among supplied products. The amount of imported food products at the end of 2019 was 1.8 billion dollars.

The fourth and fifth places among the leading importers of Russian food products were occupied by South Korea and Egypt, respectively, importing goods worth approximately $\$$ 
1.5 billion. The share of each country in the total volume of Russian food exports was about $7 \%$. Fish and crustaceans accounted for the overwhelming majority of foodstuffs exported to South Korea, while wheat and sunflower oil are the dominant positions in Egyptian imports from Russia.

The sixth place is occupied by Byelorussia, which in 2019 imported from Russia food products worth 1.3 billion dollars. The largest position of Belarusian imports are rape seeds, as well as bakery, confectionery and sunflower oil.

The top 10 buyers of Russian food products are Azerbaijan. This country imported $\$ 0.6$ billion worth of food from Russia in 2019, which is five times less than the export of the leading position of China. Export of goods to Azerbaijan accounted for almost 3\% of all exports of Russian food.

Thus, the structure of agro-food exports is far from perfect in terms of counteragent countries. Insufficient share is occupied by trade with major strategic partners of Russia within BRICS. Analysis of statistical data on the volume of food products allows to identify negative and positive trends in market development, predict consumer demand and its impact on the economy.

Decree of the President of the Russian Federation №560 of 09.08.2014. "On the application of certain special economic measures to ensure the security of the Russian Federation" prohibits the import of certain types of agricultural products, raw materials and food into the country. Russia's response measures imply a thorough analysis of the opportunities and reserves of the domestic agro-industrial complex in solving the problem of import substitution. In 2014, the rate of import substitution and reduction of the country's food dependency will be taken. The positive dynamics of increase of domestic agro-industrial complex production volume and decrease of import supplies share were noted [11].

In order to analyze the dynamics between the export and import of foodstuffs of Russia, it is necessary to calculate the indicator of foreign trade balance on the basis of open statistical data on the agricultural sector of the country, presented on the official website of Rosstat using the formula (1):

Foreign trade balance $=$ Export-Import $(1)$

$1.2017=\$ 20.7$ billion $-\$ 28.88$ billion $=\$-8.18$ billion .

2. $2018=\$ 24.91$ billion $-\$ 29.68$ billion $=\$-4.77$ billion.

3. 3. $2019=\$ 9.51$ billion $-\$ 13.34$ billion $=\$-3.83$ billion .

For illustrative comparison of changes in the foreign trade balance in the food market from 2017 to 2019, we will present the data obtained in Figure 1.

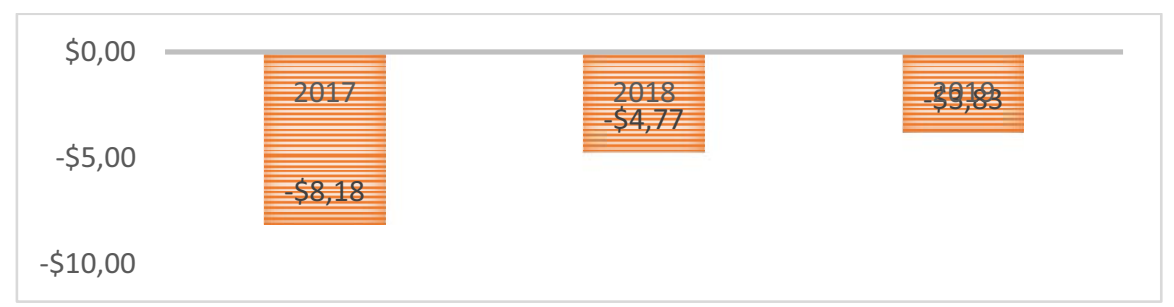

Fig. 1. Foreign trade balance of food products in Russia for the period from 2017 to 2019

At the end of 2015, the maximum reduction in the share of imported products for the analyzed period of 2014-2019 was achieved: the volume of imports decreased by 1.5 times compared to the previous year and amounted to $\$ 25393.0$ million, which was the result of the introduction of economic sanctions against Russia and Russia's response. By the end of 2016 , there was also a decrease in the amount of imported food products by almost $\$ 2$ billion. This indicates a decrease in Russia's food dependency. Combined with a slight decrease in exports by $\$ 2$ billion to $\$ 1,4652.0$ million by 2016 , the negative food trade balance still shows an excess of imports over exports, but over the period 2015-2016 there is a positive trend. 
Since 2017, food imports have been increasing annually. The largest growth was observed in 2017: the volume of imported products grew by $\$ 4$ billion to $\$ 2,7504.3$ million. Later on, the accelerated growth of imported foodstuffs in Russia was avoided, and by the end of 2019 its volume amounted to $\$ 28390.0$ million.

In the period from 2017 to 2019, Russia's food imports always prevail over Russia's food exports. If we take into account that every year the difference between exports and imports decreases significantly, that is, the probability that Russia's food production will develop effectively in the near future, despite the new reality and threats.

Export of Russian products at the end of 2017-2018 showed an absolute increase of $\$ 3,320$ million and $\$ 4,247$ million respectively, which indicates an increase in the Russian food industry. By the end of 2019, the volume of exports decreased by approximately USD 1 billion to USD 21180.0 million.

Resolution of the Government of the Russian Federation No. 717 dd. 14.07.2012 (ed. 31.03.2020) "On the State Program for the Development of Agriculture and Regulation of Markets in Agricultural Products, Raw Materials and Foodstuffs" for the period 2013-2025 sets a number of goals and objectives for Russia aimed at sustainable development of agricultural sectors. According to the adopted document, the second stage of the State Program sets the goal of step-by-step approaching the growth rate of agricultural exports in 2025 at the rate of $210.6 \%$ compared to the level of 2017 (Table 2).

Table 2. Target indicators of growth rates of agro-industrial complex export for 2018-2025 [1]

\begin{tabular}{|c|c|}
\hline in 2017 (base year) & $100,0 \%$ \\
\hline in 2018 & $106,5 \%$ \\
\hline in 2019 & $111,1 \%$ \\
\hline in 2020 & $115,7 \%$ \\
\hline in 2021 & $129,6 \%$ \\
\hline in 2022 & $157,4 \%$ \\
\hline in 2023 & $189,8 \%$ \\
\hline in 2024 & $208,3 \%$ \\
\hline in 2025 & $210,6 \%$ \\
\hline
\end{tabular}

According to the results of 2018, the growth rate of the agro-industrial complex export amounted to $123.6 \%$ as compared to the baseline value of 2017 , which is 17.1 p.p. higher than the planned export level. After a decline in food exports by the end of 2019, the growth rate was $117.8 \%$ compared to the base year. Despite the decline in exports abroad, the actual value meets the target of $111.1 \%$ set for 2019 by the program.

Proceeding from the results of the analysis and comparing the obtained indicators with the planned ones, it can be concluded that the Russian export economy of food products meets the target of achieving the set growth rate of export of goods, however, the implementation of import substitution direction in recent years leaves much to be desired, as the share of imported products in the country is growing.

\section{Discussion}

State programs to almost double the volume of agricultural exports by 2024 may be difficult to implement due to a number of problems that arose in the spring of 2020. Throughout March and April 2020, the food market was faced with temporary restrictions on shipments of grains, cereals, flour, oilseeds and various essential goods abroad. It was decided to introduce a quota for grain export for the period from April to June, as well as a ban, 
according to which the Eurasian Economic Commission is obliged to suspend the sale of onions, garlic, turnips, rye, rice, buckwheat, millet, cereals and flour abroad. Such a situation cannot but affect the implementation of plans on the volume of exports for the projected longterm period. Russian statesmen and analysts of the leading food companies provide estimates of the decrease of the Russian export after the world market exit from the crisis [2].

At the end of 2019 Russia started exporting its products to 19 new countries. According to the estimates of the head of the Ministry of Agriculture, a significant achievement of Russia in early 2020 was the successful agreements with China on the supply of meat products, and the targets of the state project on food export in 2020 will be fully met, despite the shaken economy in the uncertain spread of coronavirus.

The demand for the products of Russia's largest producers of meat products in the amount of $28 \%$ of the company's export volume in physical terms at the end of 2019 falls on China, which has now overcome the peak of the epidemic. At the beginning of 2020 the industry faced difficulties in maintaining trade and economic relations with the country as usual, however, at present shipments to China are increasing against the backdrop of growing demand for chicken wings and legs - traditional Chinese cuisine, as cafes and restaurants are resuming operations [13]. Changing commodity flows of the organization (due to the closure of fast food restaurants in the U.S., some of the supplies are forced to go to other countries) has affected the balance of supply and demand, which is a strategic factor in forecasting the entire industry. A major threat in this situation would be to break relations with Europe as the main export destination [9].

The situation of uncertainty in the further development of trade turnover in the world has touched upon the transport communication. Prices for various transportations have increased by almost a quarter. Difficulties have been encountered in the delivery to the quarantined cities. However, experts emphasize the fact that in the conditions of the Coronavirus pandemic, the demand for food not only has not decreased, but is also increasing, only the structure of consumption has changed: the goods are now sent not to the public catering sector, but to processors [14]. Manufacturers have to work on a more demanded assortment list [7].

\section{Conclusion}

Thus, the effectiveness of the food market after overcoming the crisis associated with the spread of a particularly dangerous infection is determined by two factors: regulation of export by the state by the main food suppliers and support for domestic producers of food products. At present, analysts find it difficult to predict price volatility on world exchanges. Measures taken to prevent coronavirus pandemics have a strong impact on world trade. Due to the shock of demand for different types of products, prices collapsed in many markets. Negative demand shock came even to the countries of European and US leaders, which had to close their borders and reduce trade flows.

The author draws attention to the importance of the state in the field of control and regulation of the country's food products market. In addition to the fact that the ability to provide the population with its own products grows over the years, the state can artificially restrict access and participants in the market of food products, although they are in a zone of limited rationality due to external effects, still ensure an even distribution of resources. The behavior of food market participants at the macroeconomic level shows significant similarities with the technology of decision making by certain market participants at the micro level. Decision-making is affected by the introduction of sanctions and the current sanitary and epidemiological situation, which, in sum, gives limited access to information and asymmetry of its distribution. Overlapping interests of the state and food market 
participants force the inclusion of the mechanism of switching institutions to implement effective state policy on the food market.

\section{References}

1. S.A. Al-Thaqeb, B.G. Algharabali, Economic policy: A literature review Journal of Economic Asymmetries, 20, 00133 (2019)

2. S.R. Baker, N. Bloom, S.J. Davis, Measuring economic policy uncertainty Quarterly Journal of Economics, 131(4), 1593 (2016)

3. C.D. Carroll, Quarterly Journal of Economics, 112(1), 55 (1997)

4. N.C. Churchill, J.W. Mullins, Harvard business review, 79(5), 135 (2001)

5. T. Eggertsson, Selected Essays, The Myth of Eternal Return, Images and Symbols, Sacred and worldly (2000)

6. Federal Centre for Export Development of the Ministry of Agriculture of the Russian Federation, http://aemcx.ru/

7. I. M. Gogolev, N. V. Shishov, Problems of Regional Economy, 3(4), 134 (2019)

8. M.D. Hill, G.W. Kelly, M.J. Highfield, Net Operating Working Capital Behavior: A First Look Financial Management, 39(2), 783 (2010)

9. B. Julio, Y. Yook, Journal of Finance, 67(1), 45 (2012)

10. L.J. MacCini, A. Pagan, Inventories, fluctuations, and goods sector cycles Macroeconomic Dynamics, 17(1), 89 (2013)

11. M.S. Oborin, Vestnik of Samara State Economic University, 2, 48 (2018)

12. V.S. Osipov, Advances in Intelligent Systems and Computing, 1100 AISC, 272 (2020)

13. A.E. Shastitko, New institutional theory (2002)

14. N.G. Sidorova, V.S. Osipov, A.G. Zeldner, Smart Innovation, Systems and Technologies, 138, 56 (2020) 